\title{
Efficient heterologous expression of an alkaline lipase and its application in hydrolytic production of free astaxanthin
}

\author{
Jinjin Huang ${ }^{1,2+}$, Zhen Yang ${ }^{1 \dagger}$, Ruiyan Zhu ${ }^{3}$, Xinxin Qian ${ }^{1}$, Yaqiu Wang ${ }^{1}$, Ying $\mathrm{Li}^{1^{*}}$ and Jilun $\mathrm{Li}^{1}$
}

\begin{abstract}
Background: Astaxanthin, a naturally occurring carotenoid pigment molecule, displays strong antioxidant, anti-cancer, and immunity-enhancing properties, and is often utilized in food, biomedical, cosmetic, and other industries. Free astaxanthin has better solubility than astaxanthin esters (Ast-E), and is a useful auxiliary ingredient in health foods and medicines. Our goal was to establish an improved enzymatic method for preparation of free astaxanthin from natural sources (e.g., the microalga Haematococcus pluvialis), to expand the potential applications of free astaxanthin.
\end{abstract}

Results: The alkaline lipase gene proalip and its propeptide were cloned and successfully fusion-expressed in Pichia pastoris $X$-33. The recombinant lipase was termed Lipase-YH. Through optimization of culture conditions (medium formulation, $\mathrm{pH}$, added methanol concentration), cell growth $\left(\mathrm{OD}_{600}\right)$ and secreted enzyme activity respectively reached to 280 and $2050 \mathrm{U} / \mathrm{mL}$ in a 50-L autofermentor. Activity of Lipase-YH enzyme powder was about 40,000 U/g. Hydrolysis of Ast-E (extracted from H. pluvialis) by Lipase-YH occurred in aqueous phase, and reaction conditions were optimized based on emulsification method and enzyme/substrate ratio. The highest enzymatic reaction rate was observed for substrate concentration $200 \mu \mathrm{g} / \mathrm{mL}$, with maximal free astaxanthin yield (80\%) at $1 \mathrm{~h}$, and maximal Ast-E hydrolysis rate $96 \%$, as confirmed by TLC, HPLC, and mass spectroscopy.

Conclusion: A novel, efficient enzymatic process was developed for production of free astaxanthin through hydrolysis of Ast-E. Lipase activity was enhanced, and production cost was greatly reduced. The unique structure of free astaxanthin allows linkage to various functional compounds, which will facilitate development of novel pharmaceutical and food products in future studies.

Keywords: Haematococcus pluvialis, Free astaxanthin, Alkaline lipase, Heterologous expression, Hydrolysis

\section{Background}

Astaxanthin ( $3,3^{\prime}$-dihydroxy- $\beta, \beta$-carotene- $4,4^{\prime}$-dione) is the principal carotenoid pigment in algae, yeasts, plants, crustaceans, and certain fish (notably salmon) [1-3]. It has molecular formula $\mathrm{C}_{40} \mathrm{H}_{52} \mathrm{O}_{4}$ and molecular weight 596.86. Astaxanthin has a long conjugated double bond, similar to other carotenoids, but the benzene ring at each end of the carbon chain has a hydroxyl group and

\footnotetext{
*Correspondence: yingli528@vip.sina.com

${ }^{\dagger}$ Jinjin Huang and Zhen Yang contributed equally to this work

${ }^{1}$ State Key Laboratory of Agrobiotechnology and MOA Key Laboratory of Soil Microbiology, College of Biological Sciences, China Agricultural University, Beijing 100193, China

Full list of author information is available at the end of the article
}

a ketone [4]. The unique molecular structure of astaxanthin confers a strong ability to remove oxygen free radicals and to inhibit singlet oxygen [5]. The antioxidant activity of naturally occurring astaxanthin is about 10 times higher than that of $\beta$-carotene, and about 100 times higher than that of vitamin $E$, resulting in the nickname "super vitamin E" [5-7]. Astaxanthin has been found to display anti-cancer, anti-aging, immunity-enhancing, and other beneficial physiological effects in many studies, and is often utilized in the food, biomedical, cosmetic, and animal feed industries [8-12].

The terminal structure of the astaxanthin molecule contains a hydroxyl group that can form an ester linkage with fatty acid to generate astaxanthin esters (Ast-E). 
Both free astaxanthin and Ast-E are strongly hydrophobic. Addition of certain groups to hydroxyl groups of free astaxanthin can increase solubility, which is useful for preparation of derivatives for oral administration; e.g., derivatives based on astaxanthin disuccinic acid disodium salt have been applied for treatment of various neurological disorders [13]. Derivatives based on free astaxanthin have been successfully used in nutraceutical and medicinal preparations for treatment of degenerative diseases [14].

Antarctic shrimp (Pandalus borealis) and microalga Haematococcus pluvialis are the richest known sources of natural astaxanthin, which constitutes $2-3 \%(\mathrm{w} / \mathrm{w})$ of cell dry weight [15-17]. However, free astaxanthin accounts was only $5 \%(\mathrm{w} / \mathrm{w})$ of total astaxanthin in H. pluvialis, while astaxanthin monoester and diester account was, respectively, 70 and 25\% [18]. A major problem to be solved for efficient preparation of astaxanthin derivatives is how to convert these large amounts of Ast-E into free astaxanthin.

Nagao's group used a two-step process involving two types of lipase to produce free astaxanthin [19]. Triglyceride was hydrolyzed by Candida rugosa lipase, the by-product fatty acid was removed by molecular distillation, Ast-E was concentrated, and substrate reaction was catalyzed by Pseudomonas aeruginosa lipase, resulting in free astaxanthin content $89.3 \%$ after 110 h reaction [19]. Ast-E from Euphausia superba Dana was hydrolyzed by C. rugosa lipase (lipase type VII) and cholesterol esterase from $P$. fluorescens, using bile salts as emulsions to investigate fatty acid composition of astaxanthin [20]. Halldorsson et al. found that lipases from Pseudomonas, Geotrichum candidum, Rhizopus delemar, R. oryzae and Penicillium roqueforti also functioned as catalysts with the ability to hydrolyze astaxanthin diester to produce monoester; however, only C. rugosa lipase produced free astaxanthin, with maximal content (73\%) attained after $42 \mathrm{~h}$ reaction [21]. The above-described free astaxanthin production processes were all time-consuming and had low conversion rates.

In a 2011 study, we screened various lipases, and observed highest enzyme specificity for a lipase termed ALIP [4]. We obtained free astaxanthin by hydrolysis of total esters extracted from $H$. pluvialis cells by a one-step hydrolysis method, with maximal yield (63.2\%) reached after $7 \mathrm{~h}$ enzymatic reaction at $25-28{ }^{\circ} \mathrm{C}$ [4]. Three problems remained to be solved: (i) ALIP gene was cloned from Penicillium cyclopium var. albus and expressed in Pichia pastoris GS115, but enzyme activity of ALIP needs to be improved; (ii) Buffered complex glycerol/methanol medium (BMGY/BMMY) is a high-cost medium not suitable for extended, large-scale enzyme production; (iii) the grinding method used to emulsify Ast-E is time-consuming, may lead to oxidation of Ast-E, and is not suitable for large-scale production; the reaction process should be completed within a short time.

Our goal in the present study was to improve enzyme activity and increase free astaxanthin yield, to substantially increase astaxanthin solubility for biomedical and nutritional applications. We constructed a recombinant lipase and optimized the enzyme production process and hydrolysis conditions, resulting in significant enhancement of enzyme activity and catalytic efficiency, and reduction of production cost.

\section{Results}

Enzyme activity enhancement by added propeptide fusion expression

Amino acid (a.a.) sequence of $P$. cyclopium var. albus lipase (ALIP) was obtained from GenBank (Seq ID \# AAF82375.1), and the signal sequence was predicted by SignalP-4.0 Server program (http://www.cbs.dtu.dk/ services/SignalP/). ALIP contained a 20-a.a. signal peptide (Additional file 1: Fig. S1A), and a 7-a.a. propeptide was found at the start of the 258-a.a. mature lipase (Additional file 1: Fig. S1B) [22]. Some propeptides play important roles in folding and secretion of enzymes [23]. We, therefore, investigated the effect of the 7-a.a. propeptide on heterologous expression of ALIP. Lipase gene with propeptide (proalip; $795 \mathrm{bp}$ ) and without propeptide (malip; $774 \mathrm{bp}$ ) was obtained by PCR, using $P$. cyclopium var. albus cDNA as template. Two gene fragments were each connected to two vectors PPICZ $\alpha \mathrm{A}$ and pPICM $\alpha$ A [24], resulting in four recombinant plasmids termed pPICZ $\alpha \mathrm{A}$-proalip, pPICM $\alpha \mathrm{A}-$ proalip, pPICZ $\alpha \mathrm{A}$ malip, and pPICM $\alpha \mathrm{A}-$ malip. Each of these plasmids was transformed to $P$. pastoris $\mathrm{X}-33$ by electroporation, and positive recombinant strains z $\alpha$-proalip-X33, $\mathrm{m} \alpha$-proalip-X33, z $\alpha$-malip-X33, and $\mathrm{m} \alpha$-malip-X33 were successfully screened.

Four transformants were selected for shake-flask fermentation with BMGY/BMMY, using original strain 9K-malip-GS115 [4] as control. Sampling and detection were performed at 24-h intervals. After $168 \mathrm{~h}$, measured enzyme activities of m $\alpha$-malip-X33, z $\alpha$-malip-X33, $\mathrm{m} \alpha$-proalip-X33, and z $\alpha$-proalip-X33 were, respectively 12.2-25.4, 36.6-47.5, 238.4-287.3, and 246.2-307.8 U/ $\mathrm{mL}$ (Table 1). Enzyme activities of m $\alpha$-proalip-X33 and z $\alpha$-proalip-X33 (pro-ALIP) were higher than those of 9K-malip-GS115 $(133.4 \mathrm{U} / \mathrm{mL})$ and of recombinant without propeptide (12.2-47.5 U/mL).

Extracellular and intracellular target proteins were detected using identical volumes (32 $\mu \mathrm{L})$ of fermentation supernatant containing

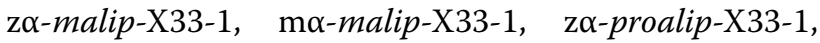
or ma-proalip-X33-1, and identical numbers of cells 
Table 1 Extracellular enzyme activity of various recombinant strains in flask fermentation

\begin{tabular}{lrlr}
\hline Strain & $\begin{array}{l}\text { Enzyme } \\
\text { activity } \\
(\mathbf{U} / \mathbf{m L})\end{array}$ & Strain & $\begin{array}{l}\text { Enzyme } \\
\text { activity } \\
(\mathbf{U} / \mathbf{m L})\end{array}$ \\
\hline ma-malip-X33-1 & $25.4 \pm 2.2$ & ma-proalip-X33-1 & $287.3 \pm 22.8$ \\
ma-malip-X33-2 & $22.4 \pm 3.9$ & ma-proalip-X33-2 & $238.4 \pm 18.9$ \\
ma-malip-X33-3 & $12.2 \pm 2.5$ & ma-proalip-X33-3 & $266.5 \pm 36.3$ \\
ma-malip-X33-4 & $15.3 \pm 2.6$ & ma-proalip-X33-4 & $257.1 \pm 42.1$ \\
za-malip-X33-1 & $47.5 \pm 7.8$ & za-proalip-X33-1 & $307.8 \pm 25.5$ \\
za-malip-X33-2 & $42 \pm 4.7$ & za-proalip-X33-2 & $261 \pm 18.2$ \\
za-malip-X33-3 & $45.8 \pm 5.6$ & za-proalip-X33-3 & $246.2 \pm 21.7$ \\
za-malip-X33-4 & $36.6 \pm 3.2$ & za-proalip-X33-4 & $274.6 \pm 43.6$ \\
9K-malip-GS115 & $133.4 \pm 7.3$ & & \\
\hline
\end{tabular}

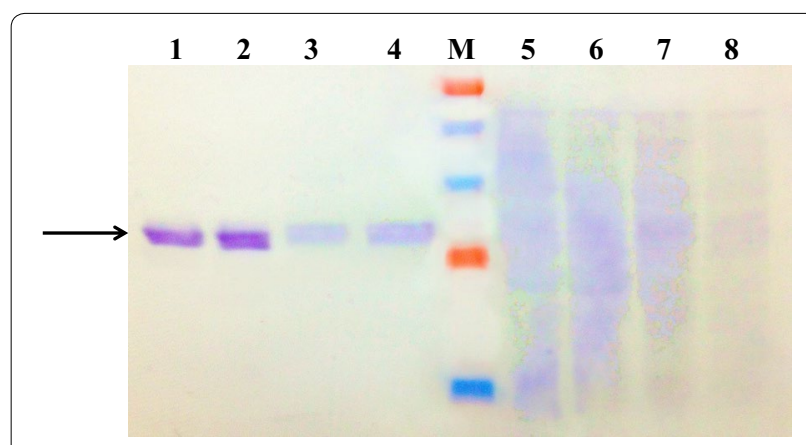

Fig. 1 Extracellular and intracellular proteins of four recombinant strains detected by Western blotting. Lanes 1-4: fermentation supernatants of za-proalip-X33-1, ma-proalip-X33-1, ma-malip-X33-1, and za-malip-X33-1. Lanes 5-8: broken-cell intracellular fluids of the four strains. Lane M: molecular weight markers $(100,60,45,28$, $18 \mathrm{kDa}$ ). Arrow: target protein. Extracellular target proteins proALIP ( $30 \mathrm{kDa}$ ) and mALIP ( $26 \mathrm{kDa}$ ) (arrow) were found in broths of the four strains. Target proteins did not accumulate within cells

of the four recombinants. Extracellular target protein pro-ALIP $(30 \mathrm{kDa})$ was detected in z $\alpha$-proalip-X33-1 and mo-proalip-X33-1 supernatants (Fig. 1, lanes 1, 2; arrow). mALIP (26 kDa) was found in ma-malip-X33-1 and z $\alpha$-malip-X33-1 broths (lanes 3,4 ). No target protein band was observed in disrupted cell solution (lanes 5-8), and there was no significant protein accumulation in the four recombinants. These findings indicate that addition of the 7-a.a. propeptide from the start of ALIP promotes protein expression. Secretion was enhanced sixfold than za-malip-X33 $(47.5 \mathrm{U} / \mathrm{mL})$. The strain showing highest lipase secretion $(307.8 \mathrm{U} / \mathrm{mL})$, produced from recombinant za-proalip-X33-1, was selected for subsequent experiments. This strain was termed $\mathrm{X} 33-\mathrm{YH}$, and its secreted lipase was termed Lipase-YH.

A comparison of optimal temperature and optimal $\mathrm{pH}$ of ALIP with and without the propeptide is shown in Additional file 2: Table S1. Optimal reaction temperature range for ALIP was $35-40{ }^{\circ} \mathrm{C}$, whereas Lipase-YH maintained high enzyme activity in a broader range $30-50{ }^{\circ} \mathrm{C}$. Optimal reaction $\mathrm{pH}$ of ALIP (8.0) was higher than that of Lipase-YH (7.5).

\section{Optimization of culture conditions}

To promote large-scale production of Lipase-YH and reduce associated cost, we optimized fermentation $\mathrm{pH}$, formulation of yeast nitrogen base without a.a. (YNB) (see M\&M) (Table 2), and methanol concentration in medium for maximal production. Similar results were obtained for three batches. Effects of fermentation $\mathrm{pH}$ and methanol concentration on enzyme activity are shown in Fig. 2, and those of BMMY containing various YNB formulations are shown in Table 2, using averaged data of three repeats from a typical batch.

Effects of fermentation $\mathrm{pH}(5.0,6.0,6.5,7.0)$ on extracellular enzyme activity in shake-flask fermentation were observed. Cell density $\left(\mathrm{OD}_{600}\right)$ and enzyme activity were measured in samples taken at 24-h intervals. Density as a function of time was very similar for $\mathrm{pH}$ values in the range $6.0-8.0\left(\mathrm{OD}_{600}=68\right.$ at $\left.120 \mathrm{~h}\right)$, but was notably lower for $\mathrm{pH} 5.0\left(\mathrm{OD}_{600}=52\right.$ at $\left.120 \mathrm{~h}\right)$ (Fig. 2a). Enzyme activity consistently increased as $\mathrm{pH}$ increased from

Table 2 Effects of media with various YNB formulations on cell density (OD600) and enzyme activity of X33-YH cultured for $124 \mathrm{~h}$

\begin{tabular}{|c|c|c|c|c|}
\hline YNB type & Components of YNB & BMMY medium & $O D_{600}(124 h)$ & $\begin{array}{l}\text { Enzyme activity } \\
(124 \mathrm{~h})(\mathrm{U} / \mathrm{mL})\end{array}$ \\
\hline a1-YNB & $\begin{array}{l}\text { Nitrogen source, vitamins, trace } \\
\text { elements, macronutrients }\end{array}$ & a1-BMMY & $63.34 \pm 2.16$ & $623.3 \pm 10.8$ \\
\hline a2-YNB & $\begin{array}{l}\text { Nitrogen source, trace elements, } \\
\text { macronutrients }\end{array}$ & a2-BMMY & $63.55 \pm 1.94$ & $600.2 \pm 15.2$ \\
\hline a3-YNB & Macronutrients & a3-BMMY & $63.48 \pm 1.29$ & $615.6 \pm 12.7$ \\
\hline$c-Y N B$ & With commercial YNB & c-BMMY & $64.24 \pm 3.15$ & $584.8 \pm 21.7$ \\
\hline$n-Y N B$ & Without YNB & n-BMMY & $13.41 \pm 1.22$ & $10.8 \pm 1.8$ \\
\hline
\end{tabular}



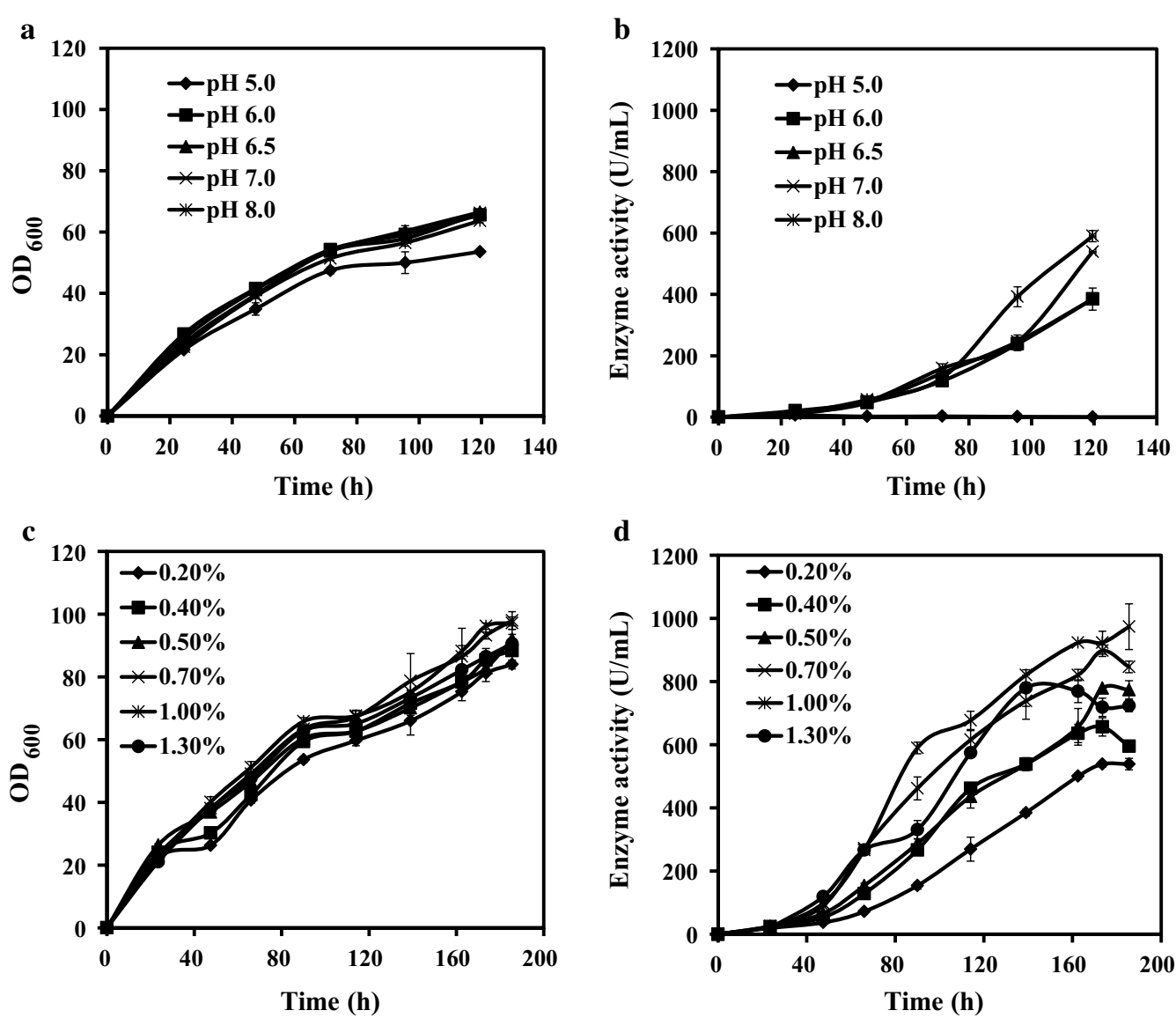

Fig. 2 Cell density and extracellular enzyme activity of X33-YH under various culture conditions in flask fermentation. a Effect of culture pH on cell density $\left(\mathrm{OD}_{600}\right)$. $\mathbf{b}$ Effect of $\mathrm{pH}$ on enzyme activity. $\mathbf{c}$ Effect of added methanol concentration on cell density. $\mathbf{d}$ Effect of added methanol concentration on enzyme activity. pH and methanol concentration had no notable effect on cell density, but did affect enzyme activity. Optimal values for Lipase-YH expression in shake-flask culture were $\mathrm{pH} 7.0-8.0$ and methanol 1.0\%; resulting enzyme activity was $972 \mathrm{U} / \mathrm{mL}$

5.0 to 8.0 , and maximal value $(577 \mathrm{U} / \mathrm{mL}$ at $120 \mathrm{~h}$ ) was observed for pH 7.0-8.0 (Fig. 2b).

The most expensive component of BMMY is YNB. The formulation of YNB is based on ingredients in four categories: (i) nitrogen source (ammonium sulfate $5.0 \mathrm{~g} / \mathrm{L}$ ); (ii) vitamins (biotin $2 \mu \mathrm{g} / \mathrm{L}$, folic acid $2 \mu \mathrm{g} / \mathrm{L}$, calcium pantothenate $400 \mu \mathrm{g} / \mathrm{L}$, inositol $2 \mathrm{mg} / \mathrm{L}, P$-aminobenzoic acid $200 \mu \mathrm{g} / \mathrm{L}$, thiamin hydrochloride $400 \mu \mathrm{g} / \mathrm{L}$, riboflavin $200 \mu \mathrm{g} / \mathrm{L}$, pyridoxine hydrochloride $400 \mu \mathrm{g} / \mathrm{L}$ and nicotinamide $400 \mu \mathrm{g} / \mathrm{L}$ ); (iii) trace elements $\left(\mathrm{CuSO}_{4} 40 \mu \mathrm{g} / \mathrm{L}, \mathrm{FeCl}_{3}\right.$ $200 \mu \mathrm{g} / \mathrm{L}, \mathrm{ZnSO}_{4} 400 \mu \mathrm{g} / \mathrm{L}, \mathrm{MnSO}_{4} 400 \mu \mathrm{g} / \mathrm{L}$, boric acid $500 \mu \mathrm{g} / \mathrm{L}$, potassium iodide $100 \mu \mathrm{g} / \mathrm{L}$ and sodium molybdate $200 \mu \mathrm{g} / \mathrm{L}$ ); (iv) macronutrients $\left(\mathrm{KH}_{2} \mathrm{PO}_{4} 0.85 \mathrm{~g} / \mathrm{L}\right.$, $\mathrm{K}_{2} \mathrm{HPO}_{4} 0.15 \mathrm{~g} / \mathrm{L}, \mathrm{NaCl} 0.1 \mathrm{~g} / \mathrm{L}, \mathrm{CaCl}_{2} 0.1 \mathrm{~g} / \mathrm{L}, \mathrm{MgSO}_{4}$ $\left.0.5 \mathrm{~g} / \mathrm{L},\left(\mathrm{NH}_{4}\right)_{2} \mathrm{SO}_{4} 5 \mathrm{~g} / \mathrm{L}\right)$. In an effort to reduce cost, we tested commercially available YNB (cat \# BD291930, Becton Dickinson; Franklin Lakes, NJ, USA), artificial YNB containing all components (termed a1-YNB), artificial YNB without vitamins (termed a2-YNB), and artificial
YNB containing only macronutrients (termed a3-YNB) in shake-flask fermentation to determine optimal YNB formulation. The formulations are summarized in Table 2. a1-, a2-, and a3-YNB were added separately to BMMY (mixtures termed a1-BMMY, a2-BMMY, and a3-BMMY). To assess effects of each YNB component on shake-flask Lipase-YH production, we performed concurrent experiments using BMMY with a1-YNB, a2-YNB, a3-YNB, commercial YNB (see M\&M) (c-BMMY), and without YNB (n-BMMY). Following addition of $1 \%$ methanol, samples were taken at 24-h intervals for measurement of enzyme activity and cell density $\left(\mathrm{OD}_{600}\right)$ (see $\left.\mathrm{M} \& \mathrm{M}\right)$, and final values were measured at $124 \mathrm{~h}$. Extracellular enzyme activity values were similar for culture of recombinant strain $\mathrm{X} 33-\mathrm{YH}$ in BMMY containing c-YNB (623.3 U/mL), a1-YNB (600.2 U/mL), a2-YNB (615.6 U/mL), and a3-YNB $(584.8 \mathrm{U} / \mathrm{mL})$ (Table 2). In striking contrast, the value for culture in medium without YNB (n-YNB) was only $10 \mathrm{U} / \mathrm{mL}$, indicating that macronutrients (but not other 
components as above) in medium are essential for Lipase$\mathrm{YH}$ production.

We next optimized concentration of added methanol in medium for induction of Lipase-YH production in X33-YH. Methanol concentration was successively increased $(0.2,0.4,0.5,0.7,1.0,1.3 \%)$ by addition at $24-\mathrm{h}$ intervals, and samples were taken for measurement of $\mathrm{OD}_{600}$ and enzyme activity. Cell density was not notably affected by alteration of methanol concentration, and highest $\mathrm{OD}_{600}$ values were in the 85-90 range (Fig. 2c). Extracellular enzyme activity increased from 568 to $972 \mathrm{U} / \mathrm{mL}$ as methanol concentration increased from 0.2 to $1.0 \%$, but then dropped to $788 \mathrm{U} / \mathrm{mL}$ when methanol concentration $1.3 \%$ (Fig. $2 \mathrm{~d}$ ). We concluded that methanol concentration $1.0 \%$ in medium was optimal for inducing Lipase-YH expression. Simultaneous application of the three optimized conditions as above (fermentation $\mathrm{pH}, \mathrm{YNB}$ formulation, methanol concentration) resulted in increase of enzyme activity from 307.8 to $972 \mathrm{U} / \mathrm{mL}$, with reduction of culture medium cost.

\section{Enzyme activity $2000 \mathrm{U} / \mathrm{mL}$ was attained in $50-\mathrm{L}$ autofermentor}

We next cultured $\mathrm{X} 33-\mathrm{YH}$ in a $50-\mathrm{L}$ autofermentor, using optimized culture conditions as above. The three processing phases were glycerol batch phase, metal ion mixture fed-batch phase, and methanol induction phase (see $\mathrm{M} \& \mathrm{M} /$ “Fermentation in 50-L autofermentor”). Samples

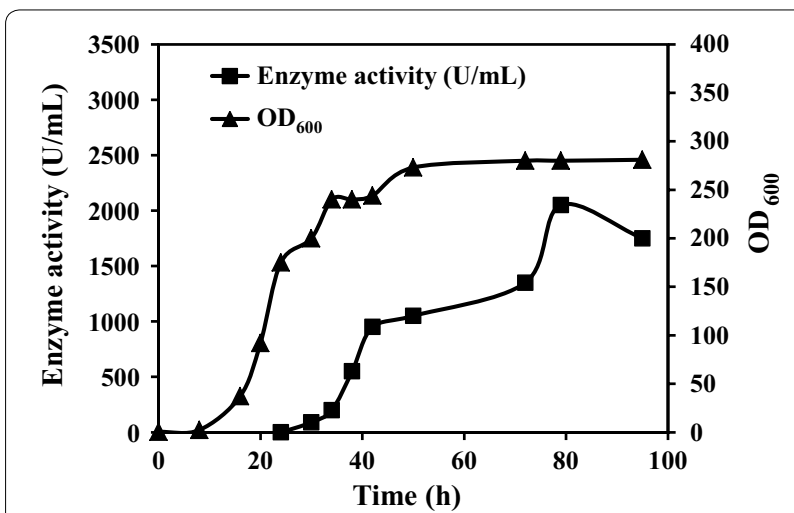

Fig. 3 Cell density and extracellular enzyme activity of X33-YH in 50- $\mathrm{L}$ autofermentor. Enzyme activity reached $2050 \mathrm{U} / \mathrm{mL}$ and cell density $\left(\mathrm{OD}_{600}\right)$ reached 280 after $79 \mathrm{~h}$ culture were taken at 4-h intervals for measurement of enzyme activity and cell density $\left(\mathrm{OD}_{600}\right)$. Consistent results were obtained in multiple experiments; a representative example is shown in Fig. 3. Maximal $\mathrm{OD}_{600}$ value (172) was observed at the end of metal ion mixture fed-batch phase (24 h), when $0.5 \%$ methanol was added. Enzyme activity in extracellular increased rapidly between 24 and $79 \mathrm{~h}$, although cell growth was slow. Enzyme activity reached $2050 \mathrm{U} / \mathrm{mL}$, with $\mathrm{OD}_{600}$ value 280 , at $79 \mathrm{~h}$. In comparison with results using a 7.5-L autofermentor (culture time $96 \mathrm{~h}$, maximal enzyme activity $1575 \mathrm{U} / \mathrm{mL}$ ) (Additional file 3: Fig. S2), the 50-L autofermentor had significantly lower culture time $(79 \mathrm{~h})$ and higher enzyme activity $(2050 \mathrm{U} / \mathrm{mL})$.

For preparation of enzyme powder, fermentation broth was centrifuged at $4000 \mathrm{rpm}$ for $5 \mathrm{~min}$ at $4{ }^{\circ} \mathrm{C}$, and $150 \mathrm{~mL}$ supernatant was added with acetone as precipitant and then dried at room temperature. Similar results were obtained in three repeated experiments, and average values are shown in Additional file 4: Table S2. Optimal supernatant/acetone ratio was 1.0: $2.4(\mathrm{v} / \mathrm{v}), 5.05 \mathrm{~g}$ enzyme powder was extracted from $150 \mathrm{~mL}$ supernatant, and total enzyme activity was $20 \times 10^{4} \mathrm{U}$ (Additional file 4: Table S2), which is about $40,000 \mathrm{U} / \mathrm{g}$.

\section{Preparation of free astaxanthin}

Lipase activity and free astaxanthin production were compared for various recombinant strains. Effects of propeptide on astaxanthin hydrolysis were analyzed using equal amounts of added enzyme. Lipase activity of za-malip-X33-1 fermentation supernatant was only $47 \mathrm{U} / \mathrm{mL}$; therefore, $\mathrm{X} 33-\mathrm{YH}, \mathrm{m} \alpha-$ proalip-X33-1, and 9K-malip-GS115 fermentation supernatants were diluted with distilled water to give the same enzyme activity. Equal amounts of enzyme were added to $10-\mathrm{mL}$ reaction system, Ast-E (about $86 \mu \mathrm{g}$ ) was added to achieve activity level $4.6 \mathrm{U} / \mu \mathrm{g}$, and the mixture underwent reaction for $7 \mathrm{~h}$ at $30^{\circ} \mathrm{C}$. $500-\mu \mathrm{L}$ samples were taken at 0 and $7 \mathrm{~h}$ for TLC analysis. Ast-E content in Lipase-YH catalytic system and enzyme production by mo-proalip-X33-1 (Fig. 4a, lanes 3,4$)$ was less than in zo-malip-X33-1 and 9K-malipGS115 systems (lanes 5, 6), and free astaxanthin content was greater. These findings indicate that lipase activity was enhanced by addition of propeptide, thus improving efficiency of catalytic substrates for production of free astaxanthin.

(See figure on next page.)

Fig. 4 Hydrolysis of Ast-E by Lipase-YH. a TLC analysis. Lane 1: free astaxanthin. Lane 2: reaction at 0 h. Lane 3: Lipase-YH produced by X33-YH. Lane 4: pro-ALIP produced by ma-proalip-X33-1. Lane 5: mALIP produced by 9K-malip-GS115. Lane 6: mALIP produced by za-malip-X33-1. b HPLC analysis of Ast-E hydrolysis catalyzed by Lipase-YH enzyme powder dissolved in water. c HPLC spectrum at 0 h. d HPLC spectrum at 2 h. e MS of peak at RT $=16.006$ min. Lipase-YH hydrolyzed Ast-E into free astaxanthin, as confirmed by TLC and HPLC. When Lipase-YH enzyme powder dissolved in water was used as catalyst, free astaxanthin yield reached $57.1 \%$ 
a
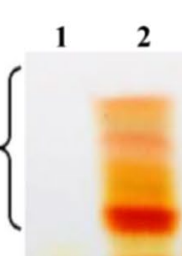

Free astaxanthin

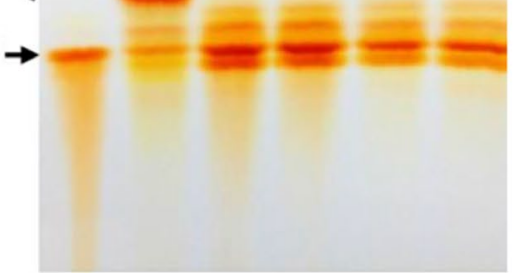

c

b
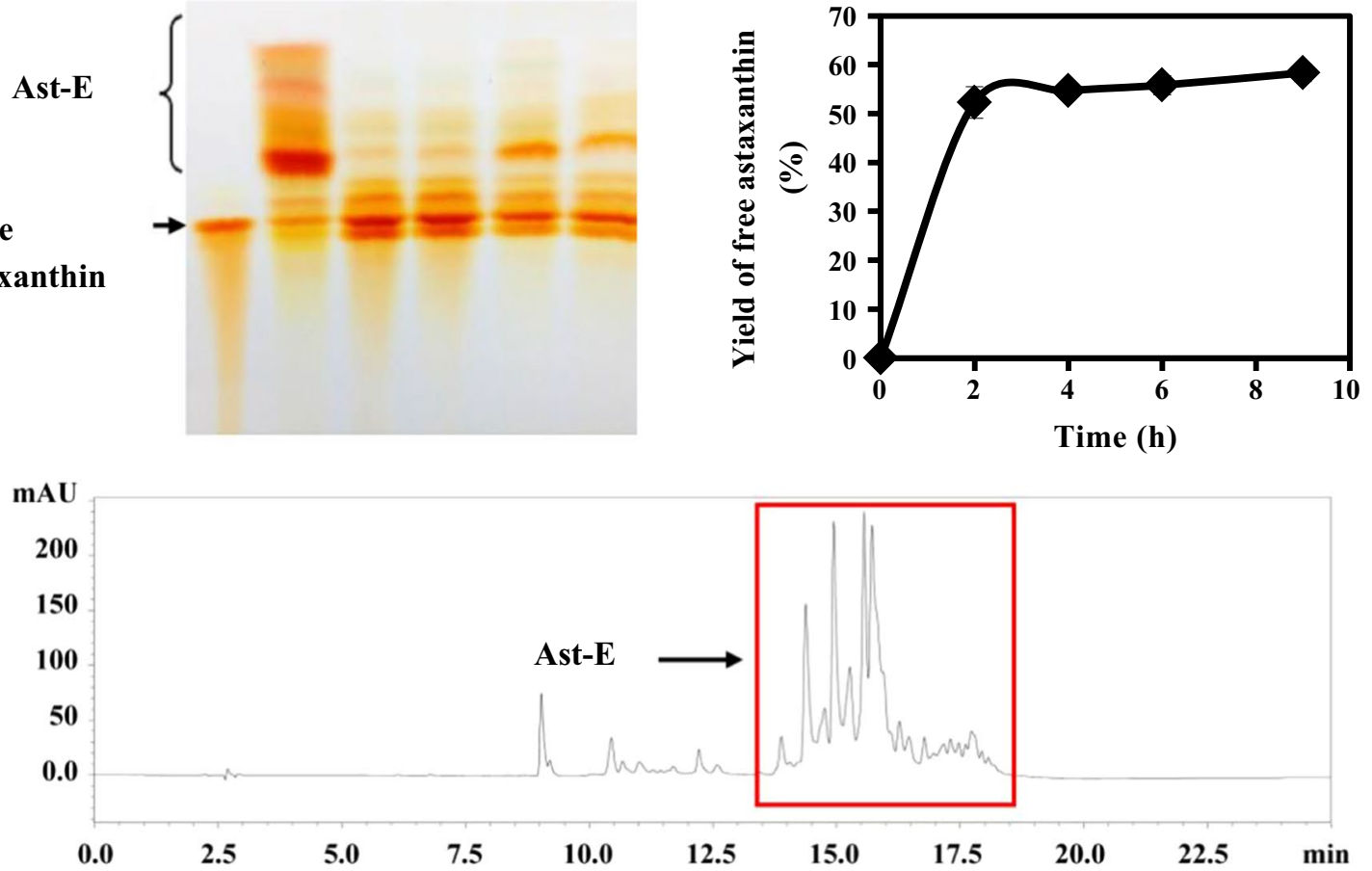

d

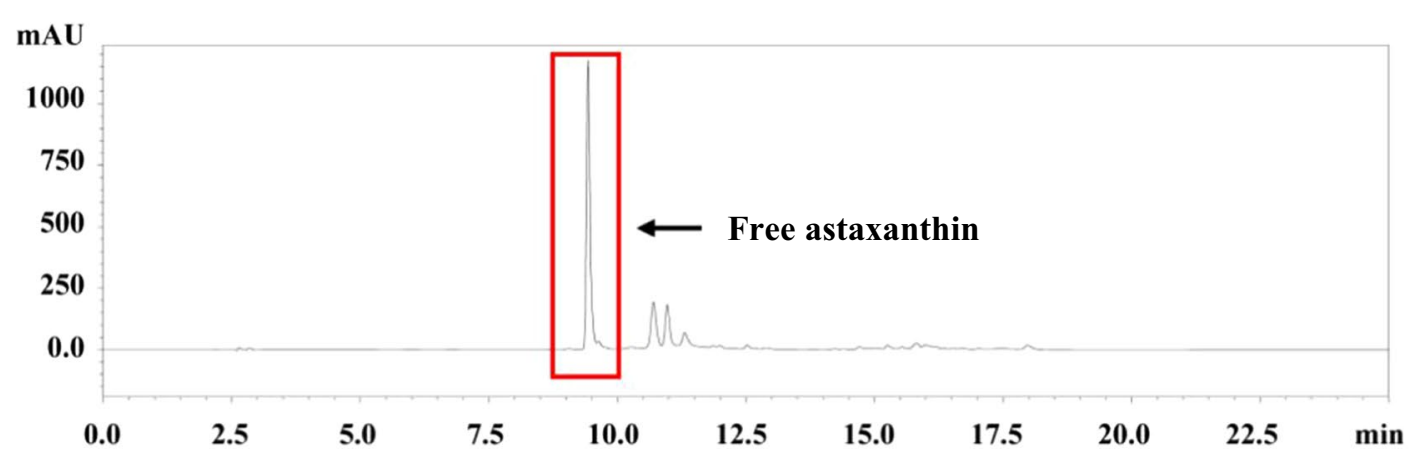

e

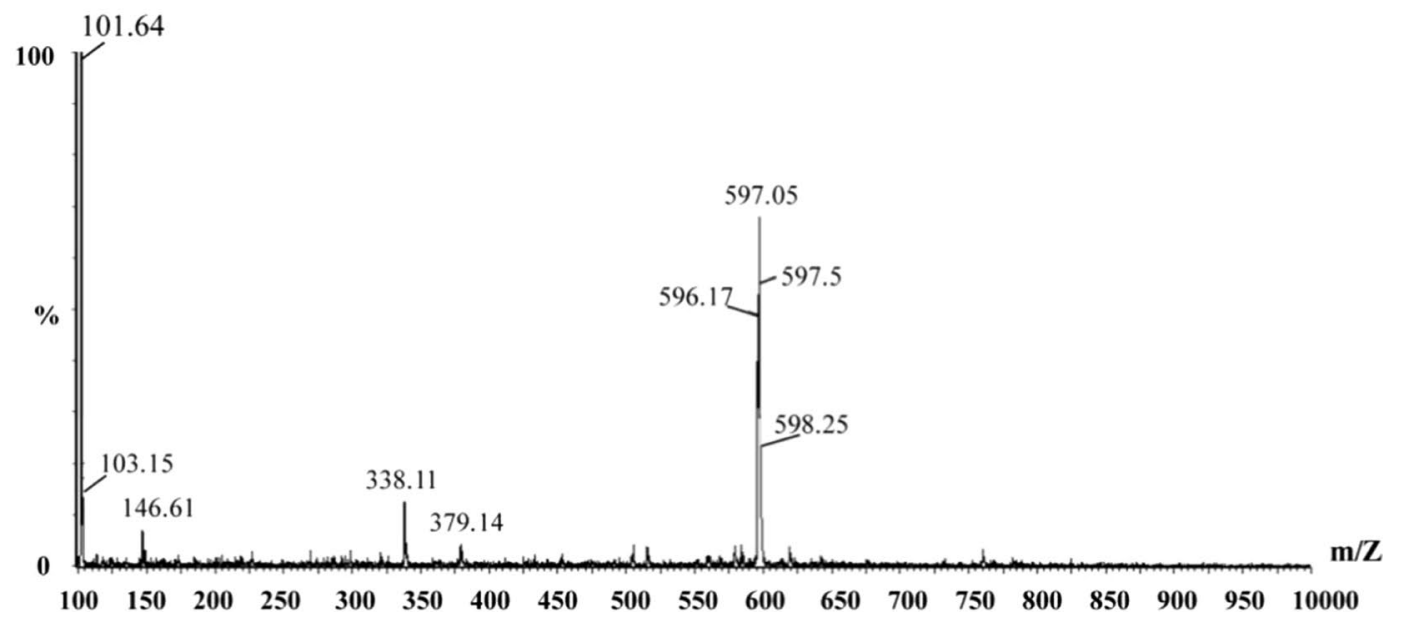


Catalysis of astaxanthin hydrolysis by Lipase-YH enzyme powder dissolved in water was evaluated. Reaction conditions were: substrate (Ast-E) concentration about $25 \mu \mathrm{g} / \mathrm{mL}$, enzyme concentration $20 \mathrm{U} / \mathrm{g}$ substrate in $10 \mathrm{~mL}$ sodium phosphate buffer $(\mathrm{pH} 7.0), 9 \mathrm{~h}$ reaction at $30{ }^{\circ} \mathrm{C}$. Samples were taken every $2-3 \mathrm{~h}$ and analyzed by HPLC. After $9 \mathrm{~h}$, free astaxanthin content was $57.1 \%$, and Ast-E content was $13.7 \%$ (Fig. 4b). Ast-E was abundant at $0 \mathrm{~h}$ (Fig. 4c), but a large proportion underwent hydrolysis into free astaxanthin by $2 \mathrm{~h}$ (Fig. $4 \mathrm{~d}$ ). The product shown in Fig. 4d was isolated and purified for MS analysis (Fig. 4e), and confirmed as free astaxanthin. These findings demonstrate that the enzyme powder dissolved in water is effective for free astaxanthin production.

\section{Optimal conditions for free astaxanthin production}

To obtain maximal yield of free astaxanthin, enzymatic hydrolysis of Ast-E was performed in $10-\mathrm{mL}$ reaction volume, and reaction conditions (enzyme concentration, buffer concentration, reaction $\mathrm{pH}$, substrate concentration) were optimized. Reaction product was quantitatively analyzed by HPLC. All data mentioned below are averages of three repeats in one of three batches showing similar results.

For each reaction system, substrate concentration was kept constant and various enzyme concentrations (5, 10, 20, 40, $80 \mathrm{U} / \mu \mathrm{g}$ Ast-E) were tested. Enzyme concentration was positively correlated with enzyme reaction speed. For the highest enzyme concentration $(80 \mathrm{U} / \mu \mathrm{g}$ Ast-E), free astaxanthin yield increased rapidly to $42 \%$ at $15 \mathrm{~min}$, and then more slowly to its maximal value (59\%) by $9 \mathrm{~h}$ (Fig. 5a).

Effects of various sodium phosphate buffer (pH 7.0) concentrations $(0.05,0.1,0.2,0.5,1.0 \mathrm{M})$ on free astaxanthin yield were evaluated with other parameters held constant. Samples were taken at intervals and analyzed by HPLC. Free astaxanthin yield was about $56.0 \%$ at
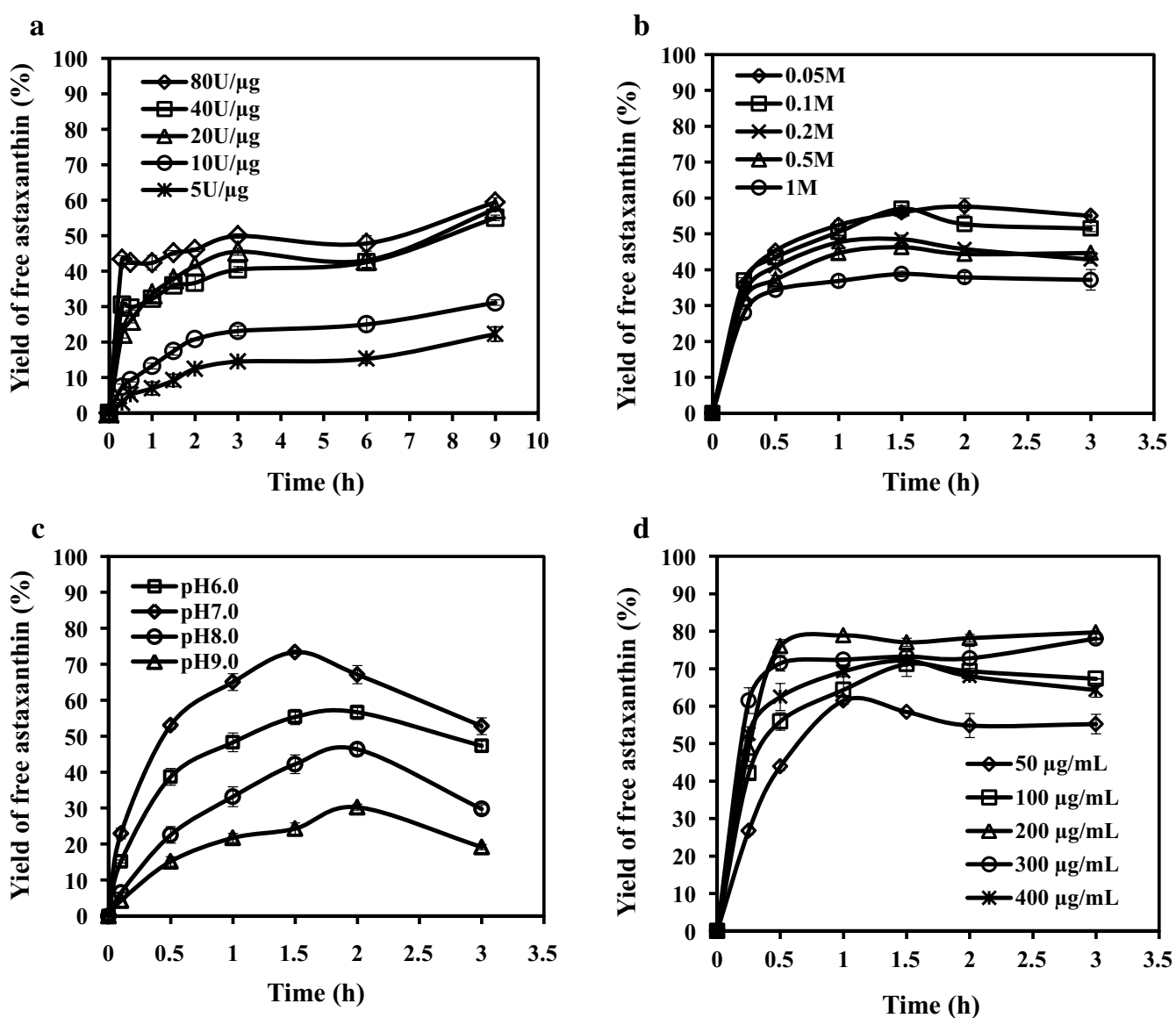

Fig. 5 Hydrolysis of Ast-E by Lipase-YH, analyzed by HPLC. a Effect of enzyme concentration on free astaxanthin yield. $\mathbf{b}$ Effect of buffer (sodium phosphate buffer, $\mathrm{pH}$ 7.0) concentration on free astaxanthin yield. $\mathbf{c}$ Effect of pH on free astaxanthin yield. $\mathbf{d}$ Effect of substrate concentration on free astaxanthin yield. After $1 \mathrm{~h}$ culture at $\mathrm{pH} 7.0$, substrate concentration $200 \mu \mathrm{g} / \mathrm{mL}$, and buffer concentration 0.05 or $0.1 \mathrm{M}$, enzyme concentration reached $80 \mathrm{U} / \mu \mathrm{g}$ Ast-E, and free astaxanthin yield reached its maximal value (80\%) 
$1.5 \mathrm{~h}$ for buffer concentrations 0.05 and $0.1 \mathrm{M}$, and less for higher buffer concentrations (Fig. 5b).

In $\mathrm{pH}$ experiments, free astaxanthin yield increased as $\mathrm{pH}$ rose from 6.0 to 7.0, but declined at higher $\mathrm{pH}$ (8.0, 9.0) (Fig. 5c). At pH 7.0, free astaxanthin yield was highest $(73.8 \%)$ at $1.5 \mathrm{~h}$, and declined for longer durations.

With enzyme concentration kept constant at $80 \mathrm{U} / \mu \mathrm{g}$ Ast-E, effects of various substrate concentrations $(25,50$, $100,200 \mu \mathrm{g} / \mathrm{mL}$ ) were investigated. Hydrolytic production rate and free astaxanthin yield increased as substrate concentration increased from 25 to $200 \mu \mathrm{g} / \mathrm{mL}$ (Fig. 5d). For substrate concentration $200 \mu \mathrm{g} / \mathrm{mL}$, enzymatic reaction was fastest, and free astaxanthin yield was $71.2 \%$ after $15 \mathrm{~min}$. Reaction speed declined thereafter, and free astaxanthin yield decreased slightly. Maximal free astaxanthin yield (80.0\%) was observed at $1 \mathrm{~h}$, and maximal Ast-E hydrolysis rate was $96 \%$.

Following optimization of reaction conditions as above, we expanded the reaction to 0.5 - and 1.0-L systems, and observed free astaxanthin yields and hydrolysis rates similar to those in the 10-mL reaction system. Three batches were performed, with three repeats for each batch. Similar results were obtained for the three batches, and averaged data for one typical batch are shown in Table 3. These findings indicate that optimized conditions for free astaxanthin production we determined in small systems can be successfully extended to larger systems.

\section{Discussion}

We established an enzymatic process for production of free astaxanthin, a useful compound in the food, biomedical, and cosmetic industries. Enzymatic processes, in comparison with chemical reactions, are generally regarded as efficient, mild, and environmentally friendly. Enzyme activity, enzyme stability, and hydrolysis conditions are key factors in free astaxanthin production and associated cost.

Factors that affect heterologous protein expression include gene structure, signal peptide, gene dosage, propeptide, and culture conditions [24]. We successfully enhanced Lipase-YH production by adding propeptide and optimizing culture conditions. Inouye group demonstrated that a 77-a.a. propeptide organized correct

Table 3 Free astaxanthin yield and Ast-E hydrolysis rate for three reaction systems of increasing volume

\begin{tabular}{lll}
\hline Reaction volume & $\begin{array}{l}\text { Free astaxanthin } \\
\text { yield (\%) }\end{array}$ & $\begin{array}{l}\text { Ast-E } \\
\text { hydrolysis } \\
\text { rate (\%) }\end{array}$ \\
\hline $10 \mathrm{~mL}$ & $80.0 \pm 3.3$ & $96.0 \pm 4.3$ \\
$0.5 \mathrm{~L}$ & $80.2 \pm 5.1$ & $97.0 \pm 3.5$ \\
$1.0 \mathrm{~L}$ & $79.8 \pm 3.8$ & $95.3 \pm 3.7$ \\
\hline
\end{tabular}

folding of its own protease domain as an intramolecular chaperone, and that Ile to Val (I48V) mutation in the propeptide resulted in production of two subtilisins that differed in secondary structure, thermostability, and substrate specificity [25]. Propeptide sequence played a significant role in in vivo folding and secretion of active Rhizopus oryzae lipase (mROL) expressed in Saccharomyces cerevisiae [23]. In our 2014 study, addition of propeptide of Rhizomucor miehei lipase (RML) increased its expression level in P. pastoris from 56 to $430 \mathrm{U} / \mathrm{mL}$, and glycosylation was found in the propeptide [24]. In the present study, NetNGlyc 1.0 server (cbs.dtu.dk/servi ces/NetNGlyc/) predicted no glycosylation following addition of propeptide. We, therefore, hypothesized that the 7-a.a. propeptide at the start of ALIP is involved in enzyme folding and post-translational modification. Protein expression was about sixfold higher for ALIP with vs. without propeptide. Successful enzyme production was achieved using a3-BMMY in a 50-L autofermentor, with enzyme activity $>2000 \mathrm{U} / \mathrm{mL}$, and greatly reduced medium cost $(>70 \%$ lower than in previous studies; Additional file 5: Table S3). For culture in a 100-L autofermentor, production time was reduced by about $10 \mathrm{~h}$ because of increased oxygen supply. Increase of dissolved oxygen level has been reported to stimulate the methanol utilization pathway and thereby, enhance expression efficiency of heterologous protein expression [26, 27]. Further enhancement of enzyme activity and reduction of culture time in future studies, based on provision of adequate dissolved oxygen, is a strong possibility.

Commercial astaxanthin-based healthcare products use primarily Ast-E derived from $H$. pluvialis or antarctic shrimp (P. borealis) extract. Use of free astaxanthin in addition to Ast-E will expand the potential applications of this compound in the nutrition, drug, and food industries. We developed a safe, convenient method of free astaxanthin preparation using Lipase-YH. We optimized various reaction conditions to obtain maximal free astaxanthin yield in a first-generation reaction system. In contrast to methods of enzymatic preparation of free astaxanthin described by Nagao et al. [19], Grynbaum et al. [20], Halldorsson et al. [21], and Zhao et al. [4], we were able to achieve maximal free astaxanthin yield $80 \%$ and maximal Ast-E hydrolysis rate $96 \%$ with a reaction time of only $1 \mathrm{~h}$. These conditions described here may be further improved in the future. The unique structure of free astaxanthin allows linkage to various functional compounds for development of new drugs, which will expand potential applications [13].

We performed multiple pilot experiments using a small $(10 \mathrm{~mL})$ reaction system to conserve substrate, and were able to extend our optimized conditions to larger (0.5, $1.0 \mathrm{~L})$ reaction systems with similar results (Table 3). 
Subsequent steps in our ongoing studies will involve further optimization of reaction conditions through orthogonal testing, recovery of free astaxanthin from hydrolysis reaction system, and linking to specific functional compounds to further expand astaxanthin applications in various industries as above. Several problems of enzyme and reaction conditions have been resolved in these early-stage experiments. Our upcoming studies will focus on obtaining pure product and linking it to other compounds of interest.

\section{Conclusion}

We constructed a novel recombinant lipase (Lipase-YH), expressed it in $P$. pastoris $\mathrm{X}-33$, and achieved enzyme activity $2050 \mathrm{U} / \mathrm{mL}$ through modification of medium formulation and optimization of fermentation conditions. Cost of medium for enzyme production was reduced by $>70 \%$, Ast-E conversion rate reached $96 \%$, and free astaxanthin yield reached $80 \%$. A preliminary attempt was made to efficiently recover free astaxanthin by ultracentrifugation. Our findings provide a basis for future development of new drugs and food products.

\section{Methods}

\section{Construction of recombinant strains}

Mature lipase gene (malip) and pro-mature lipase gene (proalip) were cloned from P. cyclopium var. albus (GenBank accession number AF274320.1) cDNA. malip was amplified using primer pair malip-f (5'-GGAATTCGCA ACTGCTGACGCCGCT-3', EcoRI site) and malip-r (5'GCGGCCGCGCTCAGATAGCCACA-3', NotI site). proalip was amplified using primer pair proalip-f (5'CCCGGAATTCGCACCTATTTTGGAG TCGA-3', EcoRI site) and proalip-r (5'-ATAATGCGGCCGCGCT CAGA TAGCCAC-3', NotI site). Vectors used were
pPICZ $\alpha A$ (Thermo Fisher Scientific; Waltham, MA, USA) and $\mathrm{pPICM} \alpha \mathrm{A}$. pPICM $\alpha \mathrm{A}$ was derived from $\mathrm{pPICZ} \alpha \mathrm{A}$, and $\alpha$-factor codons of pPICM $\alpha \mathrm{A}$ were optimized without change of pPICZ $\alpha \mathrm{A}$ a.a. sequence [24]. Recombinant plasmids pPICZa-malip, pPICMa-malip, pPICZa-proalip, and pPICMa-proalip were constructed as described previously [28]. Plasmids and strains used in this study are listed in Table 4. Four recombinant plasmids (pPICZamalip, pPICMa-malip, pPICZa-proalip, pPICMa-proalip) were linearized by BstX I, and transformed, respectively, to $P$. pastoris $\mathrm{X}-33$ by electroporation. Electroporation and screening of target transformants were performed using an EasySelect Pichia expression kit (Thermo Fisher Scientific; Waltham, MA, USA) as per the manufacturer's instructions.

9K-malip-GS115 was constructed as described by Guan et al. [29]. malip was amplified using primer pair as above and connected to pPIC9K to construct recombinant plasmid pPIC9K-malip, using Kan screen and gene sequencing (Thermo Fisher Scientific; Waltham, MA, USA). The recombinant plasmid was linearized by SalI and electroporated into P. pastoris GS115. Electroporation and screening of target transformants were performed using Multi-Copy Pichia Expression Kit (Thermo Fisher Scientific; Waltham, MA, USA) as per the manufacturer's instructions.

\section{Optimization of flask fermentation conditions}

Flask culture of $P$. pastoris was performed using BMGY [yeast extract $1 \%(\mathrm{~g} / \mathrm{v})$, peptone $2 \%(\mathrm{~g} / \mathrm{v})$, glycerin $1 \%$ $(\mathrm{g} / \mathrm{v})] /$ BMMY [yeast extract $1 \%(\mathrm{~g} / \mathrm{v})$, peptone $2 \%$ $(\mathrm{g} / \mathrm{v}), 100 \mathrm{mM}$ potassium phosphate buffer] medium as described by $\mathrm{Hu}$ et al. [30]. Various fermentation conditions were optimized as described below.

Table 4 Plasmids and strains used in this study

\begin{tabular}{|c|c|c|}
\hline Plasmid or strain & Description & Source \\
\hline \multicolumn{3}{|l|}{ Plasmids } \\
\hline pPICZaA & Secretion expression vector with a-factor from S. cerevisiae & {$[24]$} \\
\hline PPICMaA & pPICZaA with a-factor optimized codons & {$[24]$} \\
\hline pPICZaA-malip & pPICZaA ligated with malip gene & This study \\
\hline pPICZaA-proalip & pPICZaA ligated with proalip gene & This study \\
\hline pPICMaA-malip & pPICMaA ligated with malip gene & This study \\
\hline pPICMaA-proalip & pPICMaA ligated with proalip gene & This study \\
\hline \multicolumn{3}{|l|}{ Strains } \\
\hline$x-33$ & Host strain $\left(\right.$ WT Mut $\left.{ }^{+}\right)$ & {$[24]$} \\
\hline za-malip-X33 & malip of lipase without propeptide expressed in X-33 using pPICZaA & This study \\
\hline za-proalip-X33 & proalip of lipase with propeptide expressed in X-33 using pPICZaA & This study \\
\hline ma-malip-X33 & malip expressed in X-33 using pPICMaA & This study \\
\hline ma-proalip-X33 & proalip expressed in X-33 using pPICMaA & This study \\
\hline
\end{tabular}




\section{Formulation of YNB compounds}

Formulation of yeast nitrogen base without a.a. (YNB) (cat \# BD291930; Becton Dickinson, Franklin Lakes, NJ, USA) was analyzed in terms of four parts: nitrogen source, vitamins, trace elements, and macronutrients. a1-YNB, a2-YNB, and a3-YNB (formulations shown in Table 2) were prepared artificially to retain necessary ingredients and reduce fermentation cost. They were added to BMMY medium (mixtures termed, respectively, a1-BMMY, a2-BMMY, a3-BMMY), rather than commercial YNB, for shake-flask fermentation to determine optimal YNB formulation.

\section{Methanol induction}

BMGY was used for liquid seed culture, and a3-BMMY [yeast extract $1 \%(\mathrm{~g} / \mathrm{v})$, peptone $2 \%(\mathrm{~g} / \mathrm{v}), 100 \mathrm{mM}$ potassium phosphate buffer (pH 7.0), a3-YNB 1.34\% (g/v)] was used to induce expression of target protein in flask. Increasing concentrations of methanol $(0.2,0.4,0.5,0.7$, $1.0,1.3 \%)$ in a3-BMMY were established by addition at 24-h intervals, to determine optimal amount of added methanol.

\section{Optimal fermentation $\mathrm{pH}$}

$\mathrm{pH}$ of $100 \mathrm{mM}$ potassium phosphate buffer in a3-BMMY was adjusted to $5.0,6.0,6.5,7.0$, and 8.0.

\section{Fermentation in 50-L autofermentor}

Fermentation method for 50-L autofermentor was similar to that in our previous study [31], except that primary seed was cultured in $300 \mathrm{~mL}$ BMGY and transferred into $3 \mathrm{~L}$ BMGY as second seed. Second seed was then fed into $30 \mathrm{~L}$ a3-BMMY in a 50-L autofermentor (Guoqiang; Shanghai, China) as $10 \%$ inoculum. The three processing phases were: (i) glycerol batch phase; (ii) metal ion mixture $\left(\mathrm{KH}_{2} \mathrm{PO}_{4} / \mathrm{K}_{2} \mathrm{HPO}_{4} 0.85 \mathrm{~g} / 0.15 \mathrm{~g}, \mathrm{NaCl} 0.1 \mathrm{~g}, \mathrm{CaCl}_{2}\right.$ $0.1 \mathrm{~g}, \mathrm{MgSO}_{4} 0.5 \mathrm{~g}$, glycerol $50 \% \mathrm{w} / \mathrm{v}$ ) fed-batch phase; (iii) methanol induction phase. Temperature was kept at $28{ }^{\circ} \mathrm{C}$ for phases $\mathrm{i}$ and ii, and reduced to $24{ }^{\circ} \mathrm{C}$ when target protein was induced by methanol (phase iii). $\mathrm{pH}$ was maintained at 7.0 (auto-adjusted by $\mathrm{NH}_{4} \cdot \mathrm{H}_{2} \mathrm{O}$ ) throughout the fermentation process. Agitation rate was $700 \mathrm{rpm}$, and aeration rate was $10 \mathrm{~L} / \mathrm{min}$. When initial glycerol was exhausted, metal ion mixture was fed (feed rate $18.15 \mathrm{~mL} / \mathrm{h} / \mathrm{L}$ initial fermentation volume) for $4 \mathrm{~h}$ until glycerol was completely consumed, then intermittently for $1 \mathrm{~h}$. Methanol $(0.5 \% \mathrm{v} / \mathrm{v})$ was added to induce protein expression. Samples were taken at 4-h intervals for measurement of cell density $\left(\mathrm{OD}_{600}\right)$ and secreted enzyme activity.

\section{Enzyme detection}

Lipase activity was detected by $\mathrm{NaOH}$ titration as described previously [24]. A reaction mixture consisting of 5-mL olive oil emulsion, $4 \mathrm{~mL}$ of $0.1 \mathrm{M}$ HEPES, $\mathrm{pH} 7.5$, and $1.0 \mathrm{~mL}$ supernatant was shaken $(180 \mathrm{rpm})$ for $10 \mathrm{~min}$ at $50{ }^{\circ} \mathrm{C}$. Reaction was stopped by addition of $15 \mathrm{~mL}$ ethanol. Phenolphthalein was added to the mixture as indicator and free fatty acids (FFAs) were titrated with $0.05 \mathrm{M} \mathrm{NaOH}$. One unit (U) lipase activity was defined as the amount of enzyme catalyzing production of $1 \mu \mathrm{mol}$ FFAs/min [24].

\section{Detection of target lipase protein by Western blotting}

Extracellular pro-ALIP was detected in $40-\mu \mathrm{L}$ volumes of fermentation supernatant mixture $(32 \mu \mathrm{L}$ fermentation supernatant mixed with $8 \mu \mathrm{L} 5 \times$ loading buffer, boiled for $10 \mathrm{~min}$ ). For each recombinant strain, fermentation broth was centrifuged, supernatant removed, precipitate washed three times and diluted with sterile distilled water to a defined cell density $\left(\mathrm{OD}_{600}=1.0\right)$, and $32 \mu \mathrm{L}$ diluted cells mixed with $8 \mu \mathrm{L}$ $5 \times$ loading buffer and boiled for $10 \mathrm{~min}$. Intracellular protein content of each strain was determined using $20 \mu \mathrm{L}$ of mixture as above. Stacking gel (5\%), resolving gel (12\%), primary antibody, secondary antibody, and BCIP/NBT Chromogenic reagent kit (cat \# PA111, Tiangen Biotech; Beijing, China) were as described previously [24].

\section{Enzyme powder preparation}

Enzyme powder was prepared as described by Geethanjali et al. [32]. Pre-cooled acetone was added to $150 \mathrm{~mL}$ fermentation supernatant (volume ratio 1.0:0.81.0:1.2), precipitated for $1 \mathrm{~h}$ at $-20{ }^{\circ} \mathrm{C}$, and dried at room temperature to constant weight. Enzyme powder was cold-stored and diluted to various appropriate concentrations prior to hydrolysis reactions as below. Effects of acetone concentration on enzyme powder extracted from $150 \mathrm{~mL}$ Lipase-YH fermentation supernatant were evaluated in terms of four parameters: weight of enzyme powder (dry) (g), total enzyme activity $\left(\times 10^{4} \mathrm{U}\right)$, enzyme activity per $\mathrm{g}\left(\times 10^{4} \mathrm{U}\right)$, recovery rate $(\%)$. These parameters were calculated as follows:

a. weight of enzyme powder (g): weight of dry enzyme powder obtained from $150 \mathrm{~mL}$ Lipase-YH fermentation supernatant.

b. total enzyme activity $\left(\times 10^{4} \mathrm{U}\right)$ : total enzyme activity of all enzyme powder from $150 \mathrm{~mL}$ Lipase-YH fermentation supernatant.

c. enzyme activity per $g\left(\times 10^{4} \mathrm{U} / \mathrm{g}\right)$ : enzyme activity of $1 \mathrm{~g}$ dry enzyme powder. 
d. recovery rate (\%): total enzyme activity (b) divided by total enzyme activity of $150 \mathrm{~mL}$ Lipase-YH fermentation supernatant without preparation of enzyme powder.

\section{Hydrolysis of Ast-E}

Substrate emulsion

$20 \mathrm{mg} \mathrm{H}$. pluvialis extract (Ast-E; Jingzhou Natural Astaxanthin Inc., China) was mixed with $20 \mathrm{mg}$ Tween 80 . The mixture was dissolved in $5 \mathrm{~mL}$ acetone in a $50-\mathrm{mL}$ stoppered flask and dried by nitrogen stream.

\section{Hydrolysis reaction system}

The above emulsion was added with $10-\mathrm{mL}$ sodium phosphate buffer $(0.1 \mathrm{M}, \mathrm{pH} 7.0)$, mixed with $40 \mathrm{U} / \mu \mathrm{g}$ (total carotenoids) lipase, and the flask was placed for in a water bath $\left(30^{\circ} \mathrm{C}, 180 \mathrm{rpm}\right)$ for $9 \mathrm{~h} .300 \mu \mathrm{L}$ samples were taken at time 0 and at 30-min intervals thereafter. Each sample was mixed with $500 \mu \mathrm{L}$ acetone and $300 \mu \mathrm{L}$ $n$-hexane, and centrifuged at 12,000 rpm for $2 \mathrm{~min}$.

\section{Optimization of hydrolysis conditions}

Optimal values were determined (single-factor optimization technique) for enzyme amount $(5,10,20,40,80 \mathrm{U} /$ $\mu \mathrm{g})$, reaction buffer concentration $(0.05,0.1,0.2,0.5$, $1 \mathrm{M})$, reaction buffer $\mathrm{pH}(6,7,8,9)$, and substrate concentration $(50,100,200,300,400 \mathrm{mg} / \mathrm{mL})$. An optimized small hydrolysis system was established according to proportion of each component, and then expanded to $500 \mathrm{~mL}$ and $1.0 \mathrm{~L}$.

\section{Detection of free astaxanthin by TLC, HPLC, and MS}

Astaxanthin pigment was detected by TLC on activated silica plates (Silica Gel 60, $10 \times 10 \mathrm{~cm}$, thickness $0.2 \mathrm{~mm}$; Yantai Chemical Industry Research Institute; Yantai, China) as we described previously [4]. Reaction supernatant $(60 \mu \mathrm{L})$ was subjected to HPLC analysis using a CBM-20A system equipped with SPD-M20A diode array detector (Shimadzu; Kyoto, Japan), with sample preparation and test conditions as described by Zhao et al. [4]. Mass spectroscopic (MS) analysis (LCQ Deca XP, Thermo Finnigan; San Jose, CA, USA) of free astaxanthin gave mass-to-charge ratio $(\mathrm{m} / \mathrm{z})$ of its parent ion. MS conditions were: capillary temperature $300{ }^{\circ} \mathrm{C}$, spray voltage $4.5 \mathrm{kV}$, positive ionization, and scan range 100 $1000 \mathrm{~m} / \mathrm{z}$, as described by Zhao et al. [4].

\section{Free astaxanthin calculation}

$3.0 \mathrm{mg}$ astaxanthin standard was dissolved in $10 \mathrm{~mL}$ chloroform in a $100-\mathrm{mL}$ volumetric flask in ultrasonic water bath, and volume adjusted to $100 \mathrm{~mL}$ with $n$-hexane to obtain stock solution. Various amounts (5, $10,15,20 \mathrm{~mL}$ ) of stock solution were mixed with $4 \mathrm{~mL}$ chloroform in 100-mL flasks, and volume adjusted to $100 \mathrm{~mL}$ with hexane to obtain four concentrations (1.5, 3.0, $4.5,6.0 \mu \mathrm{g} / \mathrm{mL}$ ) of astaxanthin standard solution. These solutions were measured by HPLC, and an astaxanthin standard curve was constructed relating peak area to quantity of free astaxanthin. Formulas used were:

Yield of free astaxanthin (\%)

$$
=M_{\text {free astaxanthin }} / M_{H \cdot \text { pluvialis extract }}
$$

Hydrolysis rate of Ast-E (\%) $=A_{\text {free astaxanthin }} / A_{\text {Ast-E }}$ where $M_{\text {free astaxanthin }}=$ quantity of free astaxanthin in reaction mixture (computed from standard curve); $M_{H}$. pluvialis extract = weight of $H$. pluvialis extract added to reaction mixture at $0 \mathrm{~h} ; A_{\text {free astaxanthin }}=$ peak area of free astaxanthin; $A_{\text {Ast-E }}=$ summed peak area of Ast-E.

\section{Additional files}

Additional file 1: Fig. S1. Analysis of Penicillium cyclopium var. albus lipase gene. A: Signal peptide analysis of the gene by signalP-4.0 Server program. B: Signal peptide and propeptide of the gene. A 20-a.a. signal peptide and 7-a.a. propeptide were found at the start of the 258-a.a. mature lipase.

Additional file 2: Table S1. Comparison of properties of ALIP with and without propeptide (Lipase-YH).

Additional file 3: Fig. S2. Culture of X33-YH in 7.5-L autofermentor. $\mathrm{X} 33-\mathrm{YH}$ was cultured in a 7.5-L autofermentor following optimization of culture conditions and medium formulation as described in the text. The three processing phases were glycerol batch phase, metal ion mixture fed-batch phase, and methanol induction phase. Samples were taken at 4-h intervals, and cell density $\left(\mathrm{OD}_{600}\right)$ and enzyme activity were measured. Cell density reached $\mathrm{OD}_{600}=251$ at the end of glycerol batch phase $(43 \mathrm{~h}$ ), and methanol $0.5 \%$ was added at $44 \mathrm{~h}$. Enzyme production rate increased rapidly between 45 and $60 \mathrm{~h}$, although cell growth was slow. Enzyme activity was $1125.7 \mathrm{U} / \mathrm{mL}$ at $60 \mathrm{~h}$. Metal ion mixture was added at $57 \mathrm{~h}$. Enzyme production rate declined abruptly after $60 \mathrm{~h}$, and cell density was fairly constant from 60 to $90 \mathrm{~h}$. At 96 h, enzyme activity reached its maximal value $(1575 \mathrm{U} / \mathrm{mL})$, and $\mathrm{OD}_{600}$ was 311 .

Additional file 4: Table S2. Effects of acetone concentration on LipaseYH extraction.

Additional file 5: Table S3. Comparison of cost of medium before and after using a3-YNB.

\section{Abbreviations}

a.a.: amino acid(s); MS: mass spectroscopy; BMGY/BMMY: buffered complex glycerol/methanol medium; YNB: yeast nitrogen base without amino acids; Ast-E: astaxanthin esters.

\section{Authors' contributions}

$Y L, J H$, and $Z Y$ designed the study. $J H, Z Y, R Z, X Q$, and $Y W$ performed the experiments. JL helped with analysis and discussion of results. JH, ZY, and $Y L$ wrote the manuscript. All authors read and approved the final manuscript.

\section{Author details}

${ }^{1}$ State Key Laboratory of Agrobiotechnology and MOA Key Laboratory of Soil Microbiology, College of Biological Sciences, China Agricultural University, Beijing 100193, China. ${ }^{2}$ Key Laboratory for Biotechnology on Medicinal Plants of Jiangsu Province, School of Life Sciences, Jiangsu Normal University, 
Xuzhou 221116, China. ${ }^{3}$ Applied Chemistry Key Lab of Hebei Province, Yanshan University, Qinhuangdao 066004, China.

\section{Acknowledgements}

The authors are grateful to Zhiwen Xu (General Manager, Qinhuangdao Leading Biological Agriculture Co., China) for providing access to the 50- and 100-L autofermentors, and to Dr. S. Anderson for English editing of the manuscript.

\section{Competing interests}

The authors declare that they have no competing interests.

\section{Availability of supporting data}

All data supporting the conclusions of this article are included within the manuscript and in the additional information.

\section{Consent for publication}

All authors agreed to publish this article.

\section{Ethics approval and consent to participate}

Not applicable.

\section{Funding}

This study was supported by the Chinese High Technology Research and Development Program (Grant No. 2013AA065802) and the Project for Extramural Scientists of State Key Laboratory of Agrobiotechnology (2015SKLAB06-19).

\section{Publisher's Note}

Springer Nature remains neutral with regard to jurisdictional claims in published maps and institutional affiliations.

Received: 2 February 2018 Accepted: 20 June 2018

Published online: 27 June 2018

\section{References}

1. Johnson EA, An GH. Astaxanthin from microbial sources. Crit Rev Biotechnol. 1991;11:297-326.

2. Martínezdelgado AA, Khandual S, Villanuevarodríguez SJ. Chemical stability of astaxanthin integrated into a food matrix: effects of food processing and methods for preservation. Food Chem. 2017;225:23-30.

3. Wu HJ, Niu HJ, Shao A, Wu C, Dixon BJ, Zhang JM, Yang SX, Wang YR. Astaxanthin as a potential neuroprotective agent for neurological diseases. Mar Drugs. 2015;13:5750-66.

4. Zhao YY, Guan FF, Wang GL, Miao LL, Ding J, Guan GH, Li Y, Hui BD. Astaxanthin preparation by lipase-catalyzed hydrolysis of its esters from Haematococcus pluvialis algal extracts. J Food Sci. 2011;76:643-50.

5. Naguib YM. Antioxidant activities of astaxanthin and related carotenoids. J Agric Food Chem. 2000;48:1150-4.

6. Miki W. Biological functions and activities of carotenoids. Pure Appl Chem. 1991;63:141-6.

7. Zuluaga M, Barzegari A, Letourneur D, Gueguen V, Pavon-Djavid G. Oxidative stress regulation on endothelial cells by hydrophilic astaxanthin complex: chemical, biological, and molecular antioxidant activity evaluation. Oxid Med Cell Longev. 2017;2017:8073798.

8. Parisi V, Tedeschi M, Gallinaro G, Varano M, Saviano S, Piermarocchi S. Carotenoids and antioxidants in age-related maculopathy Italian study: multifocal electroretinogram modifications after 1 year. Ophthalmology. 2008;115(324-333):e322.

9. Zhang L, Wang HD. Multiple mechanisms of anti-cancer effects exerted by astaxanthin. Mar Drugs. 2015;13:4310.

10. Shah MMR, Liang Y, Chen JJ, Daroch M. Astaxanthin-producing green microalga Haematococcus pluvialis: from single cell to high value commercial products. Front Plant Sci. 2016;7:278.

11. Liu F, Shi HZ, Guo QS, Yu YB, Wang AM, Lv F, Shen WB. Effects of astaxanthin and emodin on the growth, stress resistance and disease resistance of yellow cattish (Pelteobagrus fulvidraco). Fish Shellfish Immunol. 2016;51:125-35.
12. Vakarelova M, Zanoni F, Lardo P, Rossin G, Mainente F, Chignola R, Menin A, Rizzi C, Zoccatelli G. Production of stable food-grade microencapsulated astaxanthin by vibrating nozzle technology. Food Chem. 2017:221:289-95

13. Lockwood SF, Penn MS, Hazen SL, Bikádi Z, Zsila F. The effects of oral Cardax (disodium disuccinate astaxanthin) on multiple independent oxidative stress markers in a mouse peritoneal inflammation model: influence on 5-lipoxygenase in vitro and in vivo. Life Sci. 2006;79:162-74.

14. Rishton GM. Natural products as a robust source of new drugs and drug leads: past successes and present day issues. Am J Cardiol. 2008;101:43D-9D.

15. Sarada R, Vidhyavathi R, Usha D, Ravishankar GA. An efficient method for extraction of astaxanthin from green alga Haematococcus pluvialis. J Agric Food Chem. 2006;54:7585-8.

16. Lei A, Chen H, Shen G, Hu Z, Chen L, Wang J. Expression of fatty acid synthesis genes and fatty acid accumulation in Haematococcus pluvialis under different stressors. Biotechnol Biofuels. 2012;5:18.

17. Ambati RR, Moi PS, Ravi S. Astaxanthin: sources, extraction, stability, biological activities and its commercial applications-a review. Mar Drugs. 2014;12:128-52.

18. Lorenz RT, Cysewski GR. Commercial potential for Haematococcus microalgae as a natural source of astaxanthin. Trends Biotechnol. 2000;18:160-7.

19. Nagao T, Fukami T, Horita Y, Komemushi S, Sugihara A, Shimada Y. Enzymatic enrichment of astaxanthin from Haematococcus pluvialis cell extracts. J Am Oil Chem Soc. 2003;80:975-81.

20. Grynbaum MD, Hentschel P, Putzbach K, Rehbein J, Krucker M, Nicholson G, Albert K. Unambiguous detection of astaxanthin and astaxanthin fatty acid esters in krill (Euphausia superba Dana). J Sep Sci. 2005;28:1685-93.

21. Halldorsson A, Haraldsson GG. Fatty acid selectivity of microbial lipase and lipolytic enzymes from salmonid fish intestines toward astaxanthin diesters. J Am Oil Chem Soc. 2004;81:347-53.

22. Zhang HM, Wu MC, Guo J, Li JF. Cloning and sequence analysis of complete gene encoding an alkaline lipase from Penicillium cyclopium. Prikl Biokhim Mikrobiol. 2011;47:586-93.

23. Takahashi S, Ueda M, Tanaka A. Function of prosequence for in vivo folding and secretion of active Rhizopus oryzae lipase in Saccharomyces cerevisiae. Appl Microbiol Biotechnol. 2001;55:454-62.

24. Huang JJ, Xia J, Yang Z, Guan FF, Cui D, Guan GH, Jiang W, Li Y. Improved production of a recombinant Rhizomucor miehei lipase expressed in Pichia pastoris and its application for conversion of microalgae oil to biodiesel. Biotechnol Biofuels. 2014;7:111.

25. Shinde UP, Liu JJ, Inouye M. Protein memory through altered folding mediated by intramolecular chaperones. Nature. 1997;389:520-2.

26. Lee CY, Lee SJ, Jung KH, Katoh S, Lee EK. High dissolved oxygen tension enhances heterologous protein expression by recombinant Pichia pastoris. Process Biochem. 2003;38:1147-54.

27. Lim HK, Choi SJ, Kim KY, Jung KH. Dissolved-oxygen-stat controlling two variables for methanol induction of rGuamerin in Pichia pastoris and its application to repeated fed-batch. Appl Microbiol Biotechnol. 2003;62:342-8.

28. Menendez C, Martinez D, Trujillo LE, Mazola Y, Gonzalez E, Perez ER, Hernandez L. Constitutive high-level expression of a codon-optimized beta-fructosidase gene from the hyperthermophile Thermotoga maritima in Pichia pastoris. Appl Microbiol Biotechnol. 2013;97:1201-12.

29. Guan FF, Peng P, Wang GL, Yin T, Peng Q, Huang JJ, Guan GH, Li Y. Combination of two lipases more efficiently catalyzes methanolysis of soybean oil for biodiesel production in aqueous medium. Process Biochem. 2010:45:1677-82

30. Hu H, Gao J, He J, Yu B, Zheng P, Huang Z, Mao X, Yu J, Han G, Chen D. Codon optimization significantly improves the expression level of a keratinase gene in Pichia pastoris. PLoS ONE. 2013;8:e58393.

31. Huang JJ, Yang Z, Guan FF, Zhang SS, Cui D, Guan GH, Li Y. A novel mono- and diacylglycerol lipase highly expressed in Pichia pastoris and its application for food emulsifier preparation. Process Biochem. 2013;48:1899-904.

32. Geethanjali S, Subash A. Comparative study on precipitation techniques for protease isolation and purification from Labeo rohita Viscera. J Aquat Food Prod T. 2013;22:121-8. 